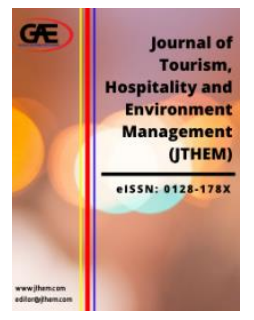

\title{
THE ROLES OF SUPPORTIVE MANAGEMENT AND EMPLOYEES' COMMITMENT TO SERVICE QUALITY TOWARDS SERVICE RECOVERY PERFORMANCE AMONG HOTEL EMPLOYEES IN MALAYSIA
}

\author{
Nuraina Nadiah Rosli ${ }^{*}$, Siti Rohaida Mohamed Zainal ${ }^{2}$ \\ 1 School of Management, Universiti Sains Malaysia, 11800 Penang, Malaysia \\ Email: nrainarosli@student.usm.my \\ 2 School of Management, Universiti Sains Malaysia, 11800 Penang, Malaysia \\ Email: siti_rohaida@usm.my \\ * Corresponding Author
}

\section{Article Info:}

\section{Article history:}

Received date: 20.01 .2020

Revised date: 24.02 .2020

Accepted date: 25.02 .2020

Published date: 15.03.2020

\section{To cite this document:}

Rosli, N. N., \& Zainal, S. R. M. (2020). The Roles of Supportive Management and Employees' Commitment to Service Quality Towards Service Recovery Performance among Hotel Employees. Journal of Tourism, Hospitality and Environment Management, 5 (18), 78-87.

DOI: 10.35631/JTHEM.518007.

\begin{abstract}
:
Service recovery performance is highly significant in the hotel sector as it ensures customers' satisfaction and loyalty. Long and inconsistent working hours and schedules, along with strenuous tasks, are the norm for jobs in the hotel sector and these challenging traits can greatly effect the job performance of hotel employees. Hence it is fundamental to identify the factors affecting their performance of service recovery. In developed countries, a large number of studies have been reported on service recovery performance. However, only a small number of such studies have been undertaken in developing countries. In addition, the number of studies on the effects of supportive management and employees' commitment to service quality in influencing their service recovery performance is also limited. Hence, the purpose of the current study is to investigate the effects of supportive management and employees' commitment to service quality towards service recovery performance, amongst 3-star hotels situated in the northern region of Peninsular Malaysia. The data was collected from a total of 104 hotel employees and analysed using the structural equation modelling-partial least square (SEM-PLS) approach. The outcomes unveiled that supportive management and employees' commitment to service quality has a significant, positive effect on service recovery performance. In conclusion, the outcomes lead to the hotel sector and the existing body of knowledge by verifying the relevance of equity theory in service recovery performance in the hotel sector framework.
\end{abstract}

Keywords:

Service Recovery Performance, Hotel, Employees 


\section{Introduction}

Malaysia tourism industry is recognized as one of the biggest contributors to the national Gross Domestic Product in 2018 amounting to $14.9 \%$ and it is expected to continuously grow in 2028 at a growing rate of $3.8 \%$. The fastest growing sector of the tourism industry now is the hotel sector and has witnessed a tremendous boom in recent years. In 2018, Malaysia received RM84.1 billion in the hotel sector and expected to show an annual growth $10.6 \%$ by 2023 . Generally, the hotel supply from 2017 to 2018 increases from 4512 hotels to 4750 (MyTourismData, 2019). With the growth in the number of hotels, the market share becomes remarkably competitive and demanding for a quality service to be provided to the hotel customers. The competitiveness of hotels depends on the quality of its service delivery because hotel customers demand a high standard of quality service. Maintaining the quality service is often difficult as it requires a high interaction between the customers and the service employees (Lewis \& McCann, 2004), which at the same time requires a high demand from the customer itself (Norhamizan Hamir, Issham Ismail, Mohd Salehuddin Mohd Zahari, \& Abdullah, 2018). The role of the employees is crucial when rendering the service to the customer especially when dealing with aggrieved customer.

Hotels in Malaysia are reportedly suffering from service failure due to the intense competition in the hotel sector. This is due to the popularity of alternative accommodations such as homestay, guest house and many more (Annuar, 2019) and complaints or negative feedback by customers as its service falls below customers' expectations (Cheema, Shah, Phanwar, Aftab, \& Zia, 2015). These are the reasons of why tourists (customers) do not opt for hotels when travelling and this is supported by the fact that the average length of stay in hotel has decreased from 5.9 nights in 2016 to 5.7 nights in 2017 (Teo, 2018). Worst of all, these issues have resulted in the shutdown of some hotels in Malaysia (Junita Mat Rasid, 2019). Therefore, hotel sector has to instil an effective service recovery handling which can help to return a dissatisfied customer to a satisfied customer after the service failure occurs (Yavas, Karatepe, Babakus, \& Avci, 2004). An effective service recovery effort by identifying the factors that help to improve the performance of the employees seems to be essential.

There is a lack of research that has been done in hotel sector area in Malaysia with only two studies were discovered to have been carried out ( e.g. (Masdek, Aziz, \& Awang, 2011; Norhamizan Hamir et al., 2018) despite many studies conducted in developed countries. Therefore, this paper aims to fill the research gap by examine the relationship between supportive management and employees' commitment to service quality towards the service recovery performance among the employees of three-star hotels in the northern region of Peninsular Malaysia.

\section{Literature Review}

\section{Service Recovery Performance}

Service recovery performance is the effectiveness of employees dealing with customer complaints to the satisfaction of employees (Boshoff \& Allen, 2000). Customers may show their dissatisfaction by making a complaint because of the service failure. There are so many examples of the occurrence of service failures in the hotel sector in which the service recovery performance is essential. For instance, no available room upon check-in, wrong bill provided, internet problem, dirty and messy room, food not cooked accordingly, and unavailable services (Luo, Guchait, Lee, \& Madera, 2019). When there is a complaint, it requires an effective service recovery effort by employees in handling the situation. Effective service recovery performance is very important because it can re-establish customer satisfaction as well as 
customer loyalty and word-of-mouth (Pai \& Yeh, 2017) and keep existing customers, while at the same time getting new customers which is considered a bonus (Kumar Piaralal, Mat, Kumar Piaralal, \& Awais Bhatti, 2014).

\section{Supportive Management}

Supportive management has been defined as concern and support by management for employee's work (Eisenberger, Armeli, Rexwinkel, Lynch, \& Rhoades, 2001; Masoud \& Hmeidan, 2013). In the supportive management of an organization, managers and supervisors sincerely recognize and appreciate hard work and are willing to correct their employees, but beyond that they are dedicated to cultivating growth. It has been proven that somehow supportive management is connected to various work-related attitudes and results. Particularly, when the employees have a perception that the institution pays particular attention towards the employees, this positively connects to their work attendance, job satisfaction, trust in management, and individual performance (Hartline, Maxham III, \& McKee, 2000; Masoud \& Hmeidan, 2013). In addition, support from management can encourage the involvement of employee and reassure them to apply their know-how and skills to come up with improvement methods in some job aspects that require improvements (Abdussalaam, Majid, Jibrin-Bida, \& Joarder, 2019). According to Masoud and Hmeidan (2013) supportive management is perceived as meaningful to organizations in regard with success and employees' commitment which will lead to successful business performance.

\section{Employees’ Commitment to Service Quality}

Employee's commitment in this study refers to employees engage in continuous improvement and put effort into their work (Oentoro \& Popaitoon, 2017; Peccei \& Rosenthal, 1997). Malhotra and Mukherjee (2004) argued that all kinds of behaviours and actions on behalf of the employees during the service encounter with customers could not be directed and controlled by supportive management alone. It is voluntary behaviour of committed employees that will largely determine business performance and satisfaction of customers. According to Piaralal, Bhatti, Piaralal, and Juhari (2016), workers who are highly committed in the business tend to perform better, put more effort, work harder and commit more time for work, along with acquire better job skills compared to workers who are less committed. In particular, the management's lack of commitment to the objective of service excellence, is directly proportionate to employee commitment towards service recovery performance. Adekola (2012) indicates that employees who show commitment towards the job will assist the organization to achieve the objectives.

\section{Hypothesis Development}

\section{Supportive management and service recovery performance}

Several previous studies found a positive relationship between supportive management and service recovery performance. A Study by Masoud and Hmeidan (2013) upon 330 four and five-star hotel frontline employees in Jordan found that supportive management was significantly related to the service recovery performance. Meanwhile, Ashill, Rod, and Carruthers (2008) conducted a study among 160 frontline employees in New Zealand public service industry also resulted in a similar finding. Therefore, this study attempts to test the following hypothesis:

H1: Supportive management has a positive relationship with service recovery performance. 


\section{Employees' Commitment to Service Quality and Service Recovery Performance}

A study conducted by Oentoro and Popaitoon (2017) among 1,235 employees who work at the call centre in a various service company in Thailand reported the significance of employees' commitment to service quality towards service recovery performance. Therefore, this study attempts to test the following hypothesis:

H1: Employees' Commitment to Service Quality has a positive relationship with service recovery performance.

\section{Research Methodology}

The study has been conducted in northern region of Peninsular Malaysia with the aim to examine the relationship between the roles (supportive management and employees' commitment to service quality) and service recovery performance in 3 star rated hotels. The reason of selected hotel because service failure frequently happened at the 3 star hotels (Jamaluddin, Hashim, \& Hanafiah, 2011) in addition, by 2022 majority of total hotel belongs to 3 star (Teo \& Chee, 2018). The study used the quantitative method based on the questionnaire survey as the research instrument. The target sample size is 92 for this study as per Gpower analysis. The respondents were chosen by using purposive sampling technique as researcher had a few inclusion criteria for selecting the respondent 1) Local employees 2) Working in current hotel for at least three years 3) Deal with customers. The data collection been conducted for two months (August 2019 to September 2019). A follow-up mail been sent to ensures the availability of the respondents to answer the questionnaire. After the availability has been set, researcher goes to respondent's location and hand delivered the questionnaire to the respondents. A total of 104 usable questionnaires from the survey, yielding response rate of $86.67 \%$. The study used a five-point Likert scale in the survey instrument, which ranging from strongly disagree (1) to strongly agree (5). The measurement items of variable supportive management adopted from (Eisenberger et al., 2001; Masoud \& Hmeidan, 2013) and variable employees' commitment to service quality adopted from (Oentoro \& Popaitoon, 2017; Peccei $\&$ Rosenthal, 1997) as presented in Table 1 and Table 2 respectively. Service recovery performance adopted from (Boshoff \& Allen, 2000) as presented in Table 3.

\section{Table 1: Measurement Items for Supportive Management}

\begin{tabular}{ll}
\hline No. & Items \\
\hline 1. & My manager/supervisor is very concerned about the welfare of those under him. \\
2. & My manager/supervisor is willing to listen to work-related problems. \\
3. & Management is willing to help me to perform my job to the best of my ability. \\
4. & Management really cares about my well-being. \\
5. & Help is available from management when I have a problem. \\
Source: ((Eisenberger et al., 2001; Masoud \& Hmeidan, 2013))
\end{tabular}

Table 2: Measurement Items for Employees' Commitment to Service Quality

\begin{tabular}{l}
\hline No. \\
\hline 1. I am always working to improve the quality of service I give to customers. \\
2. \\
3. I often have specific ideas about how to improve the service I give to customers. \\
4. $\quad$ I often make suggestions about how to improve customer service in my job. \\
Copyright $\odot$ GLOBALACADEMIC EXCELLENCE $(M) S D N B H D-$ All rights reserved
\end{tabular}


5. No matter how I feel, I always put myself out for every customer I serve.

6. I often go out of my way to help customers.

Source: (Oentoro \& Popaitoon, 2017; Peccei \& Rosenthal, 1997)

Table 3: Measurement Items for Service Recovery Performance

\begin{tabular}{cl}
\hline No. & \multicolumn{1}{c}{ Items } \\
\hline 1. & Considering all the things I do, I handle dissatisfied customers quite well. \\
2. I do not mind dealing with complaining customers. \\
3. No customers I deal with leaves with problems unresolved. \\
4. Satisfying complaining customers is a great thrill to me. \\
5. Complaining customers, I have dealt with in the past are among todays' most \\
\end{tabular}

Source: (Boshoff \& Allen, 2000)

\section{Assessment of Measurement Model}

The measurement model is analysed to determine the internal consistency reliability, convergent validity, and discriminant validity. Consistency reliability of the constructs is analysed through the composite reliability. Convergent validity of the constructs is analysed through the average variance extracted (AVE). Discriminant validity of the constructs analysed through Fornell Larcker and HTMT as suggested by (Henseler, Ringle, \& Sarstedt, 2015).

For composite reliability the threshold value is 0.70 which indicates internal consistency (Ramayah, Cheah, Chuah, Ting, \& Memon, 2018). The threshold value is 0.50 for AVE which suggested an adequate convergent validity (Hair Jr, Sarstedt, Ringle, \& Gudergan, 2017). All the constructs involved in this study were exceeded the threshold criterion. Table 4 shows the composite reliability and average variance extracted (AVE) for all the constructs.

Table 4: Assessment of Loadings, Composite Reliability and AVE

\begin{tabular}{|c|c|c|c|c|c|}
\hline No. & Construct & $\begin{array}{c}\text { Number of } \\
\text { items }\end{array}$ & Loading & CR & AVE \\
\hline 1 & $\begin{array}{l}\text { Service Recovery } \\
\text { Performance }\end{array}$ & 5 & $\begin{array}{l}0.751 \\
0.737 \\
0.787 \\
0.536 \\
0.780\end{array}$ & 0.844 & 0.524 \\
\hline 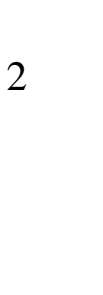 & $\begin{array}{l}\text { Supportive } \\
\text { Management }\end{array}$ & 5 & $\begin{array}{l}0.800 \\
0.797 \\
0.876 \\
0.889 \\
0.851\end{array}$ & 0.925 & 0.712 \\
\hline 3 & $\begin{array}{l}\text { Employees' } \\
\text { Commitment to } \\
\text { Service Quality }\end{array}$ & 6 & $\begin{array}{l}0.812 \\
0.694 \\
0.745 \\
0.782 \\
0.783\end{array}$ & 0.884 & 0.561 \\
\hline
\end{tabular}


The Fornell-Larcker criterion, where the square root of AVE (diagonal) is larger than its correlations (off-diagonal) for all constructs. Table 5 shows that the square root of AVE of each of the constructs is larger than its correlations with other constructs.

Table 5: Fornell and Larcker Criterion

\begin{tabular}{lccc}
\hline & $\begin{array}{c}\text { Employees' } \\
\text { Commitment to } \\
\text { Service Quality }\end{array}$ & $\begin{array}{c}\text { Service Recovery } \\
\text { Performance }\end{array}$ & $\begin{array}{c}\text { Supportive } \\
\text { Management }\end{array}$ \\
\hline $\begin{array}{l}\text { Employees' Commitment } \\
\text { to Service Quality }\end{array}$ & $\mathbf{0 . 7 4 9}$ & & \\
$\begin{array}{l}\text { Service Recovery } \\
\text { Performance }\end{array}$ & 0.683 & $\mathbf{0 . 7 2 4}$ & \\
Supportive Management & 0.457 & 0.446 & $\mathbf{0 . 8 4 4}$ \\
\hline
\end{tabular}

The values are lower than the required threshold value of HTMT that suggested by Henseler et al. (2015), which is 0.90 and the confidence interval does not show a value of one on any of the constructs, indicating the discriminant validity. Table 6 shows the values has fulfilled HTMT criterion.

Table 6: HTMT Result

\begin{tabular}{lccc}
\hline & $\begin{array}{c}\text { Employees' } \\
\text { Commitment to } \\
\text { Service Quality }\end{array}$ & $\begin{array}{c}\text { Service Recovery } \\
\text { Performance }\end{array}$ & $\begin{array}{c}\text { Supportive } \\
\text { Management }\end{array}$ \\
\hline $\begin{array}{l}\text { Employees' Commitment } \\
\text { to Service Quality }\end{array}$ & & & \\
$\begin{array}{l}\text { Service Recovery } \\
\text { Performance }\end{array}$ & 0.796 & & \\
Supportive Management & 0.526 & 0.532 & \\
\hline
\end{tabular}

\section{Assessment of Structural Model}

In order to evaluate a structural model, first the significant levels of collinearity between each predictors variables or constructs need to be assessed. The collinearity of the structural model is measured using value of variance inflation factor (VIF) (Hair Jr et al., 2017). If the value of VIF is 3.3 and higher, there is a potential of collinearity issues (Kock \& Lynn, 2012). Results of this study indicate that all the outputs are less than the common cut-off threshold of 3.3. Table 7 shows that all the value of VIF for constructs in this study.

Table 7: VIF Values

\begin{tabular}{lc}
\hline Constructs & VIF \\
\hline Employees' Commitment to Service Quality & 1.264 \\
Supportive Management & 1.264 \\
\hline
\end{tabular}


The value of $\mathrm{R}^{2}$ presents the amount of variance in the endogenous construct (service recovery performance) explained by all of the exogenous constructs (supportive management and employees' commitment to service quality). As a rule of thumb by Hair Jr et al. (2017), suggested that describes $\mathrm{R}^{2}$ values 0.25 is weak, 0.50 is moderate and 0.75 and above is substantial. Table 8 shows the $\mathrm{R}^{2}$ values, which is 0.496 , implying that $49.6 \%$ of service recovery performance is predicted by supportive management and employees' commitment to service quality.

Table 8: $\mathbf{R}^{2}$ Values

\begin{tabular}{cc}
\hline Construct & $\mathbf{R}^{\mathbf{2}}$ \\
\hline Service Recovery Performance & 0.496 \\
\hline
\end{tabular}

Next step, to evaluate the structural model to show how well the hypothesized relationship predict the research model. The path coefficient is obtained for the structural model relationships, which represent the hypothesized relationship that link the constructs by looking at the beta $(\beta), R^{2}$, and t-values. In order to evaluate the path coefficients of the research model, the t-values were evaluated using the bootstrapping procedure with 5000 samples (Henseler, Ringle, \& Sinkovics, 2009). Table 9 shows the significance results of the structural model. All the hypothesized relationship is supported at $\mathrm{p}<0.05$.

Table 9: Results of the Structural Model

\begin{tabular}{llllllll}
\hline Hypothesis & Path & Beta & t-values & p-values & LL & UL & Decisions \\
\hline H1 & SM -> & 0.195 & 2.273 & 0.012 & 0.065 & 0.348 & Yes \\
H2 & $\begin{array}{l}\text { SRP } \\
\text { ECTSQ-> }\end{array}$ & 0.539 & 9.194 & 0.000 & 0.477 & 0.700 & Yes \\
& SRP & & & & & & \\
\hline
\end{tabular}

\section{Discussions and Conclusions}

This study explores the relationship between supportive management and employees' commitment to service quality towards service recovery performance. The result of the study has found that all hypotheses are supported. The analysis of the data has found that there is a positive relationship between supportive management and employees' commitment to service quality on service recovery performance. Reviewing past researches, (Masoud \& Hmeidan, 2013; Oentoro \& Popaitoon, 2017), similar results were also found in several areas of studies such as public service and hotel.

The result conjectures that the presence of supportive management in service recovery situation is important. In this situation, a hotel employee who has supportive management would be able to work harder in handling service recovery situation without having any hesitation and difficulty. This is in line with (Abdussalaam et al. (2019); Masoud \& Hmeidan, 2013)'s statement that employee will employ their know-how and skills to propose ways for improvements in some aspects of job which need the improvements if perceived support from management. The act of supportive management does not only promote service performance at the same time enhances job performance, builds job satisfaction and reduces turnover intention among employees.

The correlation between employee's commitment to service quality and service recovery performance is found to be significant. This is in line with (Abadi, 2019; Oentoro \& Popaitoon, 2017; Okoe, Boateng, \& Mensah, 2016) the statement that when employees are highly committed, they can contribute to the success of firms by providing higher performance, more 
effort, work harder, invest more time and possess better skills in jobs. It is also hypothesized that the lack of employee commitment accounts for poor improvement efforts. Therefore, improving service recovery performance is one of their ways to show commitment.

The influence of supportive management and employee's commitment to service quality in relation with service recovery performance is vital as the empirical results support the anecdotal evidence of the relationship. These two factors (supportive management and employee's commitment to service quality) are interconnected with each other in giving a joint impact to service recovery performance. In order for the employees to successfully deal with the service recovery situation, the management must have provided the employee with enough support also, the employee must have given the job with commitment.

\section{References}

Abadi, F. (2019). The Role of Human Capital in Tour and Travel Industry. The Influence of Employee Competence, Employee Commitment and Compensation to the Employee Performance of the Tour and Travel Company. Paper presented at the 5th Annual International Conference on Management Research (AICMaR 2018).

Abdussalaam, I. I., Majid, A., Jibrin-Bida, M., \& Joarder, M. (2019). Moderating Effect of Management Support on the Relationship Between HR Practices and Employee Performance in Nigeria.

Adekola, B. (2012). The impact of organizational commitment on job satisfaction: A study of employees at Nigerian Universities. International Journal of Human Resource Studies, 2(2), 1 .

Annuar, S. S. (2019). Sektor pelancongan sumbang RM84.1 bilion, Berita Harian Retrieved from https://www.bharian.com.my/berita/nasional/2019/02/535609/sektorpelancongan-sumbang-rm841-bilion

Ashill, N. J., Rod, M., \& Carruthers, J. (2008). The effect of management commitment to service quality on frontline employees' job attitudes, turnover intentions and service recovery performance in a new public management context. Journal of Strategic Marketing, 16(5), 437-462.

Boshoff, C., \& Allen, J. (2000). The influence of selected antecedents on frontline staff's perceptions of service recovery performance. International Journal of Service Industry Management, 11(1), 63-90.

Cheema, F. A., Shah, A. A., Phanwar, I., Aftab, F., \& Zia, S. (2015). Do HR Practices Affect Service Quality of Frontline Staff? IBT JOURNAL OF BUSINESS STUDIES (JBS), 11(1).

Eisenberger, R., Armeli, S., Rexwinkel, B., Lynch, P. D., \& Rhoades, L. (2001). Reciprocation of perceived organizational support. Journal of applied psychology, 86(1), 42.

Hair Jr, J. F., Sarstedt, M., Ringle, C. M., \& Gudergan, S. P. (2017). Advanced issues in partial least squares structural equation modeling: Sage Publications.

Hartline, M. D., Maxham III, J. G., \& McKee, D. O. (2000). Corridors of influence in the dissemination of customer-oriented strategy to customer contact service employees. Journal of Marketing, 64(2), 35-50.

Henseler, J., Ringle, C. M., \& Sarstedt, M. (2015). A new criterion for assessing discriminant validity in variance-based structural equation modeling. Journal of the academy of marketing science, 43(1), 115-135.

Henseler, J., Ringle, C. M., \& Sinkovics, R. R. (2009). The use of partial least squares path modeling in international marketing New challenges to international marketing (pp. 277-319): Emerald Group Publishing Limited. 
Jamaluddin, M., Hashim, R., \& Hanafiah, M. (2011). Service failure and recovery in three-star hotel. Paper presented at the The 12th International Research Symposium on Service Excellence in Management. Cornell University, Center for Hospitality Research, School of Hotel Administration.

Junita Mat Rasid, Z. M. Y., Suzalina Halid. (2019). Airbnb jejas operasi hotel, Berita Harian. Retrieved from https://www.bharian.com.my/berita/nasional/2019/09/602604/airbnbjejas-operasi-hotel

Kock, N., \& Lynn, G. (2012). Lateral collinearity and misleading results in variance-based SEM: An illustration and recommendations. Journal of the Association for Information Systems, 13(7).

Kumar Piaralal, N., Mat, N., Kumar Piaralal, S., \& Awais Bhatti, M. (2014). Human resource management factors and service recovery performance in Malaysian life insurance industry: Exploring the moderating effects of employment status. European Journal of Training and Development, 38(6), 524-552.

Lewis, B. R., \& McCann, P. (2004). Service failure and recovery: evidence from the hotel industry. International Journal of Contemporary Hospitality Management, 16(1), 6-17.

Luo, A., Guchait, P., Lee, L., \& Madera, J. M. (2019). Transformational leadership and service recovery performance: The mediating effect of emotional labor and the influence of culture. International Journal of Hospitality Management, 77, 31-39.

Malhotra, N., \& Mukherjee, A. (2004). The relative influence of organisational commitment and job satisfaction on service quality of customer-contact employees in banking call centres. Journal of services Marketing, 18(3), 162-174.

Masdek, N., Aziz, Y. A., \& Awang, K. W. (2011). Impact of Selected Organizational Characteristics on Psychological and Behavioural Outcomes of Hotel Frontline Employees. Pertanika Journal of Social Science \& Humanity, 19 (2), 369-383.

Masoud, E. Y., \& Hmeidan, T. A. (2013). The Effect Of Perceived Work Environment On Frontline Employees'service Recovery Performance: The Case Of Four And Five Star Hotels In Jordan. European Scientific Journal, ESJ, 9(11).

MyTourismData. (2019). Hotel and Room Supply http://mytourismdata.tourism.gov.my/

Norhamizan Hamir, Issham Ismail, Mohd Salehuddin Mohd Zahari, \& Abdullah, D. (2018). The Influence of Empowerment, Rewards, and Training on Service Recovery Performance among Frontline Hotel Employees in Malaysia. International Journal of Academic Research in Business and Social Sciences, 08(15).

Oentoro, W., \& Popaitoon, P. (2017). The Role of Conscientious on Commitment to Service Quality and Service Recovery Performance. . International Journal of Crime, Law and Social Science, 04(02).

Okoe, A., Boateng, H., \& Mensah, T. (2016). The effects of job satisfaction, employee commitment, workplace friendship and team culture on service recovery performance. Management Science Letters, 6(11), 713-722.

Pai, F.-Y., \& Yeh, T.-M. (2017). The effect of Frontline Employee Efforts in Service Recovery Performance. . International Journal of e-Education, e-Business, e-Management and eLearning.

Peccei, R., \& Rosenthal, P. (1997). The antecedents of employee commitment to customer service: evidence from a UK. The International Journal of Human Resource Management, 8(1), 66-86.

Piaralal, S. K., Bhatti, M. A., Piaralal, N. K., \& Juhari, A. S. (2016). Factors affecting service recovery performance and customer service employees: A study of Malaysian life insurance industry. International Journal of Productivity and Performance Management, 65(7), 898-924. 
Ramayah, T., Cheah, J., Chuah, F., Ting, H., \& Memon, M. A. (2018). Partial least squares structural equation modeling (PLS-SEM) using SmartPLS 3.0: An updated and practical guide to statistical analysis: Pearson Singapore.

Teo, J. (2018). In Focus: Malaysia

Teo, J., \& Chee, H. Y. (2018). HVS in Focus: Malaysia https://www.hvs.com/article/8311-infocus-malaysia-reinvigorated-opportunities

Yavas, U., Karatepe, O. M., Babakus, E., \& Avci, T. (2004). Customer complaints and organizational responses: a study of hotel guests in Northern Cyprus. Journal of Hospitality \& Leisure Marketing, 11(2-3), 31-46. 